\title{
Batasan Melawan Hukum dalam Perdata dan Pidana Pada Kasus Persekongkolan Tender
}

\author{
Siti Anisah dan Trisno Raharjo \\ Fakultas Hukum UII dan Fakultas Hukum UMY \\ Jln. Tamansiswa No. 158 Yogyakarta dan Jln. Lingkar Selatan Tamantirto Bantul \\ siti.anisah@uii.ac.id; trisnoraharjo@umy.ac.id
}

Received: 5 Desember 2017; Accepted: 24 April 2018; Published: 14 Agustus 2018

DOI: 10.20885/iustum.vol25.iss1.art2

\begin{abstract}
Resolution of alleged tender conspiracy based on Law no. 5 of 1999 and Law no. 31 of 1999 in conjunction with Law no. 20 of 2001 has resulted in different decisions. This can be seen in the case of the conspiracies of the tender of the sales of two VLCC tankers Hull 1540 and 1541, Indomobil tender on May 30, 2002, procurement of legislative election ink in 2004, and electronic ID card in 2011 until 2012. This normative research analyzed the intercept between violating the existing laws in terms of criminal law and civil law, and the violation of laws both civil and criminal law in the case of tender conspiracy. The study concluded that, first, the shift in understanding about the unlawful nature (wederrechtelijk) occurs in criminal law, not only based on the criminal law (onwetmatige) but also involves the criteria of violating civil law (onrechmatige), which includes the violation of propriety in community. This is used in criminal law to interpret law violation in a material sense. Nevertheless, there are still different opinions among criminal law experts whether the nature of material law violation only has negative function or has positive function as well. Second, the violation of law that is generally defined in civil law and known in criminal law as a crime in material sense, can be limited by interpretation to determine forbidden acts known as schutznormtheorie or doctrine of relativity. Along with the understanding of law enforcement personnel and jurisprudence, it can be said that the barriers of law violation in criminal law and civil law have gone when the tender conspiracy case already violates the sense of justice in society.
\end{abstract}

Keywords: Law violation; civil; criminal; tender conspiracy

\begin{abstract}
Abstrak
Penyelesaian dugaan persekongkolan tender yang dilakukan berdasarkan Undang-Undang No. 5 Tahun 1999 dan Undang-Undang No. 31 Tahun 1999 juncto Undang-Undang No. 20 Tahun 2001 menghasilkan putusan yang berbeda-beda. Ini dapat dilihat dalam kasus persekongkolan tender penjualan dua kapal tanker VLCC No. Hull 1540 dan 1541, pelaksanaan tender Indomobil pada 30 Mei 2002, pengadaan tinta pemilu legislatif tahun 2004, dan KTP elektronik Tahun 2011 sampai 2012. Penelitian normatif ini menganalisis persinggungan antara melawan hukum yang ada dalam hukum pidana dan hukum perdata, serta batasan melawan hukum dalam hukum perdata dan pidana dalam kasus persekongkolan tender. Penelitian ini menyimpulkan, pertama, pergeseran pemahaman sifat melawan hukum (wederrechtelijk) terjadi dalam hukum pidana, tidak hanya berdasarkan undang-undang pidana (onwetmatige) namun merambah pada kriteria melawan hukum dalam hukum perdata (onrechmatige), yang mencakup pelanggaran terhadap kepatutan atau kepantasan di masyarakat. Ini digunakan dalam hukum pidana untuk memaknai melawan hukum dalam arti materiil. Namun, masih terdapat perbedaan pendapat di antara ahli hukum pidana apakah sifat melawan hukum materil hanya memiliki fungsi negatif atau juga positif. Kedua, melawan hukum yang diartikan secara luas dalam perdata dan dikenal dalam hukum pidana sebagai perbuatan melawan hukum secara materiil, dapat dibatasi melalui interpretasi guna menentukan perbuatan yang dilarang yang dikenal sebagai schutznormtheorie atau ajaran relativitas. Seiring dengan pemahaman penegak hukum dan yurisprudensi, dapat dikatakan sekat-sekat melawan hukum di dalam hukum pidana dan perdata runtuh ketika kasus persekongkolan tender telah melanggar rasa keadilan di masyarakat.
\end{abstract}

Kata-kata Kunci: Melawan hukum; perdata; pidana; persekongkolan tender 


\section{Pendahuluan}

Persekongkolan tender dalam pengadaan barang/jasa milik pemerintah menjadi kasus yang dominan dalam penanganan perkara oleh Komisi Pengawas Persaingan Usaha (KPPU). Selama 9 tahun pertama KPPU memeriksa perkara persaingan usaha, 85\% nya merupakan perkara yang berkaitan dengan pengadaan barang/jasa milik pemerintah. Persentase jumlah laporan adanya dugaan persekongkolan tender yang diterima oleh KPPU setiap tahun cenderung meningkat. Pada 2008, sebanyak 189 atau 79\% merupakan laporan adanya dugaan persekongkolan tender dari seluruhnya 230 laporan dugaan pelanggaran UndangUndang No. 5 Tahun 1999. Pada 2009, 169 laporan dari 201 laporan atau sebanyak $84 \%$ dari jumlah laporan yang ditangani oleh KPPU, merupakan laporan perkara persekongkolan tender. Selanjutnya pada 2010, KPPU telah menerima 215 laporan resmi yang terdiri dari 175 laporan tender dan 40 laporan non tender. ${ }^{1}$

Berdasarkan Laporan KPPU pada akhir 2012, inefisiensi akibat persekongkolan tender cukup besar. KPPU menyatakan bahwa persengkongkolan tender dalam proyek pemerintah pada periode 2006-2012 menyebabkan inefisiensi hingga mencapai Rp. 8.600.000.000.000,00. Inefisiensi ini setidaknya terjadi pada 173 proyek pemerintah pusat dan daerah yang menjadi perkara di KPPU. Dilihat dari 28 perkara proyek APBN sebesar Rp7,1 triliun yang ditangani oleh KPPU, 24 diantaranya terbukti ada persengkongkolan tender dengan nilai Rp. 6.600.000.000.000,00. KPPU juga memeriksa 47 perkara proyek pengadaan yang bersumber dari APBD. Sebanyak 36 dari 47 putusan dinyatakan KPPU bersengkongkol dengan nilai Rp. 1.600.000.000.000,00.2

Perkara persaingan usaha dalam pengadaan barang/jasa tersebut terkait dengan persekongkolan tender, baik horizontal atau vertikal atau gabungan antara persekongkolan horizontal dan vertikal. ${ }^{3}$ Fakta yang berhasil diungkapkan oleh

\footnotetext{
${ }^{1}$ Kasus persekongkolan tender kebanyakan berasal dari laporan masyarakat atau pelaku usaha yang tidak menang dalam tender. www.kppu.go.id/docs/laporan_tahunan/laporan\%20kppu\%202009\%20230511.pdf, Akses 12 Agustus 2010.

2 Anonim, "KPPU Nilai Inefisiensi Proyek Pemerintah Rp. 8.600.000.000.000,00," www.hukumonline.com/berita/baca/lt5105fbb6b7ac6/kppu-nilai-inefisiensi-proyek-pemerintah-rp8-6-t, Akses 28 Januari 2013.

${ }^{3}$ Persekongkolan horizontal terjadi antara pelaku usaha dengan pelaku usaha barang/jasa pesaingnya. Selanjutnya persekongkolan vertikal terjadi antara salah satu atau beberapa pelaku usaha barang/jasa dengan panitia tender atau panitia lelang atau pengguna barang/jasa atau pemilik atau pemberi jasa. Peraturan KPPU No. 2 Tahun
} 
KPPU menunjukkan bahwa persekongkolan vertikal dalam pengadaan barang/jasa, penyebabnya adalah pengkondisian oleh panitia tender, atau bahkan pejabat atasannya baik langsung atau tidak langsung dengan cara melakukan intervensi untuk menentukan pemenang tender. Dalam beberapa kasus, hal itu terkait dengan masalah kebijakan pemerintah. ${ }^{4}$ Namun demikian, dalam perkembangan selanjutnya, meskipun kebijakan pemerintah mengenai pengadaan barang/jasa telah mengarah kepada persaingan usaha yang sehat, ternyata masih terdapat celah-celah yang dapat dimanfaatkan oleh pelaku usaha untuk bersekongkol. ${ }^{5}$

Terdapat beberapa perkara tentang persekongkolan tender yang juga dikenakan pelanggaran pasal dalam hukum pidana. ${ }^{6}$ Terutama setelah perubahan arah penanganan tindak pidana korupsi di 2009 dan 2010 yang dilakukan oleh KPK. Pada 2009, tindak pidana korupsi keuangan daerah mendapat posisi pertama sebagai "ladang subur" praktik korupsi. Pada posisi kedua ditempati oleh sektor sosial masyarakat, dan posisi ketiga, di sektor pembangunan infrastruktur. Namun, penanganan perkara dugaan korupsi oleh KPK pada Semester I tahun 2010 mengalami perubahan. Korupsi di sektor keuangan daerah dan infrastruktur terlihat yang paling dominan. Aktor atau pelaku tindak pidana korupsi juga berubah drastis.

2010 tentang Pedoman Pasal 22 Undang-Undang No. 5 Tahun 1999 tentang Persekongkolan Tender, hlm. 7 - 8. Persekongkolan dalam US Antitrust Law diartikan sebagai kecurangan dalam penawaran tender. Persekongkolan tender (bid rigging) merupakan sebuah perjanjian di antara para peserta tender atau pesaing (atau yang berpotensi menjadi peserta tender/pesaing) - baik sebagai penjual atau pembeli - untuk menentukan pemenang dalam kontrak tertentu yang ditawarkan. Frank J. Vondrak, "Preventing and Detecting Bid Rigging, Price Fixing, and Market Allocation in Post-Disaster Rebuilding Projects: an Antitrust Primer for Agents and Procurement Officials" www.justice.gov/atr/preventing-and-detecting-bid-rigging-price-fixing-and-market-allocation-postdisaster-rebuilding, akses 1 Oktober 2016.

"Anonim, "Masih Ada Dualisme Pengaturan Pengadaan Jasa Konstruksi," www.hukumonline.com/berita/baca/hol15371/masih-ada-dualisme-pengaturan-pengadaan-jasa-konstruksi-, akses 29 Agustus 2006.

${ }^{5}$ Terhadap persoalan ini, KPPU telah mengidentifikasi regulasi pemerintah terkait pengadaan barang/jasa dari sudut pandang persaingan, dan telah menyampaikan beberapa saran dan/atau pertimbangan untuk mewujudkan iklim persaingan usaha yang sehat dalam pengadaan barang/jasa. www.kppu.go.id/docs/laporan_tahunan/laporan_tahunan_2008.pdf.

Di Amerika Serikat, larangan persekongkolan tender pertama kali diatur dalam Article 1 the Sherman Act 1890. Rumusan pasal itu mengandung makna bahwa perbuatan yang sifatnya kolektif (bersama) dapat dikatakan sebagai suatu persekongkolan (konspirasi). Perbuatan kolektif ini harus berupa persetujuan yang dilakukan oleh dua orang atau lebih dalam perjanjian yang dilarang, sehingga dapat dianggap telah terjadi perbuatan melawan hukum (illegal). L. Budi Kagramanto, Larangan Persekongkolan Tender (Persektif Hukum Persaingan Usaba), Surabaya: Srikandi, 2008, hlm. 174 - 175. Lihat pula Michael A. Doyle \& Michael P. Kenny, "The Statute of Limitations Applicable of Criminal Enforcement of the Sherman Act: Restraint of Trade or Enjoyment of the Spoils?" Arizona State Law Journal 183, 1986.

${ }^{6}$ Di Amerika Serikat antara tahun 1982 dan 1988, separuh lebih dari kasus pidana yang diajukan oleh Antitrust Division of the Department of Justice melibatkan persekongkolan tender dan penetapan harga di pasar lelang. Robert H. Poter and J. Douglas Zona, "Detection of Bid Rigging in Procurement Auctions," Journal of Political Economy Vol. 101 No. 3, 1993, hlm. 518. 
Pada 2009 biasanya dilakukan oleh mayoritas anggota DPR maupun DPRD, di 2010 bergeser kepada Komisaris atau Direktur perusahaan swasta. ${ }^{7}$

Persekongkolan tender dapat terjadi antara satu atau beberapa pelaku usaha dengan panitia tender atau panitia lelang, bahkan atasannya. Akibatnya adalah, selain inefisiensi dan adanya entry barries bagi kompetitor, sekaligus juga terdapat kerugian negara. Untuk itu, selain dikenakan Undang-Undang No. 5 Tahun 1999, para pihak yang terlibat dalam persekongkolan tender dapat pula dikenakan Undang-Undang No. 31 Tahun 1999 juncto Undang-Undang No. 20 Tahun 2001 tentang Pemberantasan Tindak Pidana Korupsi. ${ }^{8}$

\section{Rumusan Masalah}

Berdasarkan paparan tersebut, penelitian ini mengkaji dan menganalisis 2 hal. Pertama, bagaimana persinggungan antara melawan hukum yang ada dalam hukum pidana dan melawan hukum dalam hukum perdata? Kedua, apa batas-batas melawan hukum dalam hukum perdata dan pidana dalam kasus persekongkolan tender?

\section{Tujuan Penelitian}

Adapun mengenai tujuan peneltian pada penulisan ini adalah: pertama, mengetahui dan menganalisis persinggungan antara melawan hukum yang ada dalam hukum pidana dan melawan hukum dalam hukum perdata. Kedua, mengetahui dan menganalisis batas-batas melawan hukum dalam hukum perdata dan pidana dalam kasus persekongkolan tender

\section{Metode Penelitian}

Penelitian ini adalah penelitian hukum normatif atau doktrinal, yang menguraikan dan memberikan penjelasan sistematis terhadap regulasi, Putusan

\footnotetext{
${ }^{7}$ Anonim, "KPPU Akan Gandeng LKPP Atasi Kasus Persekongkolan Tender," www.hukumonline.com/berita/baca/lt4c6424cee54ac/kppu-akan-gandeng-lkpp-atasi-kasus-persekongkolantender, 12 Agustus 2010; Anonim"Menkeu Akui Maraknya Korupsi dalam Pengadaan Barang dan Jasa," www.hukumonline.com/berita/baca/lt4cf7563e8e446/menkeu-akui-maraknya-korupsi-di-pengadaan-barangdan-jasa-, 02 Desember 2010.

${ }^{8}$ www.hukumonline.com/berita/baca/hol15371/masih-ada-dualisme-pengaturan-pengadaan-jasakonstruksi. Pengguna jasa dalam pengadaaan barang/jasa yang notabene adalah pemerintah dapat dikenakan pasal dalam Undang-Undang No. 31 Tahun 1999 tentang Tindak Pidana Korupsi juncto Undang-Undang No. 20 Tahun 2001. Pasal 7 ayat (1) undang-undang ini mengatur mengenai pemborong yang berbuat curang dengan ancaman pidana paling lama tujuh tahun.
} 
KPPU dan Pengadilan tentang melawan hukum, khususnya dalam persekongkolan tender dan pidana korupsi. Pendekatan yang digunakan adalah perundang-undangan (statute approach), yaitu menelaah semua undang-undang dan regulasi yang bersangkut paut dengan isu hukum yang dijadikan permasalahan dalam penelitian ini, dan pendekatan kasus (case approach), yang dilakukan dengan cara melakukan telaah terhadap kasus-kasus yang berkaitan dengan permasalahan hukum yang dihadapi yang telah menjadi Putusan KPPU dan/atau pengadilan. ${ }^{9}$ Bahan hukum yang digunakan dalam penelitian ini adalah bahan hukum primer, sekunder dan tersier.

Teknik pengumpulan bahan hukum yang mendukung dan berkaitan dengan permasalahan dalam penelitian ini adalah studi dokumen (studi kepustakaan). Analisis bahan hukum dalam penelitian ini menggunakan analisis yuridis yang bersifat kualitatif. Analisis bahan hukum dilakukan dengan cara mensistematisasi bahan-bahan hukum tertulis secara menyeluruh dan merupakan satu kesatuan (holistic) terutama terhadap bahan hukum primer, selanjutnya bahan hukum sekunder atau tersier digunakan untuk menerjemahkan lebih lanjut bahan-bahan hukum primer yang tidak lengkap atau memerlukan penafsiran mendalam. Dalam hal ini, analisis bahan hukum diinterpretasi dengan menggunakan metode interpretasi sistematis, gramatikal, dan teleologis. ${ }^{10}$

\section{Hasil Penelitian dan Pembahasan}

\section{Persinggungan antara melawan hukum dalam hukum pidana dan perdata}

\section{a. Melawan hukum dalam hukum perdata}

Salah satu unsur dalam persaingan usaha tidak sehat adalah unsur "melawan hukum."11 Pengertian unsur atau indikator "melawan hukum" lebih lanjut dalam Undang-Undang No. 5 Tahun 1999 tidak dapat ditemukan, demikian pula dalam peraturan-peraturan yang dibuat oleh KPPU. Padahal Undang-Undang No. 5

9Peter Mahmud Marzuki, Penelitian Hukum, Cet 2. Kencana, Jakarta, 2008, hlm. 29.

${ }^{10}$ Interpretasi dibedakan menjadi interpretasi berdasarkan kata-kata undang-undang (leterlijk), gramatikal, berdasarkan kehendak pembentuk undang-undang, sistematis, historis, sosiologis, sosio-historis, filosofis, teleologis, holistik dan holistik. Jimly Asshiddiqie, Teori \& Aliran Penafsiran Hukum Tata Negara, Ind. Hill.Co., Jakarta, 1997, hlm. 17-18.

${ }^{11}$ Pasal 1 angka 6 Undang-Undang No. 5 Tahun 1999 mengartikan persaingan usaha tidak sehat adalah persaingan antar pelaku usaha dalam menjalankan kegiatan produksi dan/atau pemasaran barang dan/atau jasa yang dilakukan dengan cara tidak jujur atau melawan hukum atau menghambat persaingan usaha. 
Tahun 1999 mengatur secara khusus mengenai persekongkolan tender pada Pasal 22 yang di dalamnya mengandung unsur persaingan usaha tidak sehat. Dengan tidak adanya peraturan yang secara khusus menentukan unsur "melawan hukum" dalam hukum persaingan usaha, maka akan dibahas unsur "melawan hukum" sebagai salah satu unsur dalam "perbuatan melawan hukum" sebagaimana diatur dalam Pasal 1365 KUHPerdata.

Melawan hukum (onrechtmatig) dapat diartikan secara sempit maupun luas. Pengertian sempit dari melawan hukum adalah tindakan yang melanggar hak subjektif yang diatur oleh undang-undang (wettelijk subjektiefrecht) atau bertentangan dengan kewajiban hukum si pelaku yang ditentukan oleh undangundang. ${ }^{12}$ Menurut van Apeldoorn, hak subjektif adalah suatu ketentuan yang dihubungkan dengan orang tertentu dan dengan cara demikian menjadi suatu kewenangan, atau ditinjau dari sudut yang lain, suatu kewajiban. Dengan kata lain, hak subjektif adalah suatu kewenangan yang didasarkan kepada hukum objektif. Kewenangan ini bukan hanya dalam "satu" kewenangan saja, namun ada kalanya dalam wujud "sekelompok" kewenangan. Hak subjektif menunjuk kepada kebebasan bertindak yang diberikan oleh hukum perdata kepada individu dalam suatu lingkungan tertentu yang memberikan kewenangan-keputusan tertentu terhadap sesama anggota masyarakat, yang dapat menyelenggarakan dan mengurus kepentingannya. Hak subjektif dibagi menjadi hak-hak kepribadian (persoonlijkheidsrechten) dan hak kekayaan (vermogenrechten). Hak kekayaan dibagi dua, yaitu absolut dan relatif. Hak kekayaan yang absolut dibagi menjadi dua, yaitu hak-hak kebendaan dan hak-hak kekayaan absolut lainnya (misalnya hakhak atas benda-benda imaterial). ${ }^{13}$

Makna melanggar kewajiban hukum si pelaku, adalah bertindak atau mengambil sikap yang bertentangan dengan suatu undang-undang yang bersifat memerintah atau melarang. Jadi, normanya dapat dibaca dalam undang-undang yang bersangkutan. Undang-undang diartikan, baik undang-undang dalam arti

${ }^{12}$ J. Satrio, Hukum Perikatan, Perikatan yang Labir dari Undang-Undang, Bagian Pertama, Citra Aditya Bakti, Bandung, 2001, hlm. 142. Pengertian yang sempit ini mendapat pengaruh dari ajaran legisme. Rosa Agustina, Perbuatan Melawan Hukum, Fakultas Hukum Universitas Indonesia, Jakarta, 2003, hlm. 5.

13J. Satrio, Op. Cit., hlm. 163. 
formil maupun materiil. Dengan demikian, semua perbuatan yang melanggar ketentuan hukum pidana ---ditinjau dari sudut pandang hukum perdata--- adalah melawan hukum. Namun, untuk perbuatan-perbuatan melawan hukum tertentu untuk dapat dikenakan hukum pidana, seringkali harus dipenuhi syarat adanya "kesengajaan (opzet)."14

Mengingat bahwa kepentingan manusia tidak terhingga banyak dan ragamnya, sehingga tidak semua kepentingannya dapat diatur oleh hukum, hanya sebagian saja yang diberikan pengaturan dalam undang-undang dalam bentuk hak subjektif. Atas dasar pandangan itu, di samping pengertian melawan hukum dalam arti sempit, pengertian melawan hukum juga meliputi tindakan atau sikap yang bertentangan dengan ketentuan hukum yang tidak tertulis, yaitu kesusilaan dan kepatutan atau kepantasan dalam memperhatikan kepentingan diri dan harta orang lain dalam pergaulan masyarakat. ${ }^{15}$ Inilah makna melawan hukum dalam arti luas.

Suatu perbuatan melanggar kesusilaan (goede zeden) adalah melawan hukum, tidak cukup dengan mengemukakan adanya norma kesusilaan yang dilanggar, namun harus dibuktikan terlebih dahulu, bahwa norma kesusilaan itu telah diterima sebagai norma hukum. ${ }^{16}$

Jika seseorang dalam menyelenggarakan kepentingannya mengabaikan kepentingan orang lain dan membiarkan kepentingan orang lain terlanggar begitu saja, maka seseorang itu berperilaku tidak patut, dan karenanya melawan hukum. Inilah makna melanggar kepatutan atau kepantasan dalam memperhatikan kepentingan diri dalam pergaulan masyarakat. ${ }^{17}$

\section{b. Melawan hukum dalam hukum pidana}

Melawan hukum oleh pakar hukum pidana antara lain Zevenbergen, Simon, dan van Hamel disebut sebagai unsur konstitutif tindak pidana. Pandangan ini mengacu pada ajaran dalam ilmu hukum pidana Jerman, yang mengartikan melakukan tindak pidana berarti melakukan suatu tindakan yang memenuhi

\footnotetext{
${ }^{14}$ Ibid., hlm. 172.

${ }^{15}$ Ibid., hlm. 150 dan 155. Lihat pula Rosa Agustina, Op. Cit.., hlm. 19.

${ }^{16} \mathrm{~J}$. Satrio, Op. Cit.., hlm. 175.

${ }^{17}$ Ibid., hlm. 177.
} 
rumusan delik yang bersifat melawan hukum. Ajaran ini menekankan terpenuhinya unsur tindak pidana tidak berarti terbukti adanya tindak pidana sebelum membuktikan ada tidaknya perbuatan melawan hukum. Bersifat melawan hukum mutlak untuk setiap tindak pidana. Roeslan Saleh mengutip pandangan Noyon-Langemeyer mengatakan, "memidana sesuatu yang tidak bersifat melawan hukum tidak ada artinya." 18

Konsekuensi melawan hukum sebagai unsur mutlak dari delik adalah:

1) jika unsur melawan hukum tidak disebutkan dalam rumusan delik, maka unsur itu secara diam-diam dianggap telah ada di dalamnya, kecuali dibuktikan sebaliknya oleh terdakwa.

2) jika hakim ragu-ragu untuk menentukan apakah unsur melawan hukum itu ada atau tidak, maka dia tidak boleh menetapkan adanya perbuatan pidana dan oleh karenanya tidak boleh pula dijatuhkan pidana. ${ }^{19}$

Ketentuan perundang-undangan pidana Belanda, melawan hukum ada dalam setiap perbuatan yang dilarang oleh hukum pidana. Pembuktian ada tidaknya perbuatan melawan hukum baru dilakukan jika dirumuskan secara tegas sebagai unsur dalam tindak pidana. ${ }^{20}$ Hazewinkel Suringa menyatakan, bila tidak tegas dirumuskan dalam undang-undang maka melawan hukum hanya tanda dari delik. ${ }^{21}$

Istilah melawan hukum berdasarkan dogmatik hukum pidana, memiliki empat makna yang berbeda-beda. Adapun empat makna tersebut terdiri dari:22

1) Melawan hukum umum, diartikan sebagai syarat tidak tertulis untuk dapat dipidana.-Melawan hukum suatu tindak pidana berdasarkan perbuatan melawan hukum umum, tidak perlu dibuktikan namun harus dilaksanakan oleh pelaku tindak pidana.

2) Melawan hukum khusus, dirumuskan dalam delik, sehingga menjadi syarat tertulis untuk dapat dipidana. Melawan hukum berfungsi untuk dibuktikan dalam unsur tindak pidana.

3) Melawan hukum formal, terjadi bila seluruh rumusan delik dari undangundang terpenuhi. Melawan hukum formal merupakan syarat untuk dapat dipidana perbuatan dengan bersumber pada asas legalitas.

${ }^{18}$ Roeslan Saleh, Sifat Melawan Hukum dari Perbuatan Pidana, Aksara Baru, Jakarta, 1981, hlm. 1 dan 10-11.

${ }^{19}$ Ibid.

${ }^{20}$ Jan Remmelink, Hukum Pidana:Komentar atas Pasal-Pasal Terpenting dari Kitab Undang-Undang Hukum Pidana Belanda dan Padanannya dalam Kitab Undang-Undang Hukum Pidana Indonesia, Gramedia Pustaka Utama, Jakarta, 2003, hlm. 191-192.

${ }^{21}$ Roeslan Saleh, Op. Cit., hlm. 9.

${ }^{22}$ D. Schaffmeister et. al., Hukum Pidana, Citra Aditya Bakti, Bandung, 2007, hlm. 37-48. 
4) Melawan hukum materiil, berarti melanggar atau membahayakan kepentingan hukum yang hendak dilindungi oleh pembentuk undang-undang dalam rumusan delik tertentu.

Menurut ajaran melawan hukum yang materiil, disebut melawan hukum tidak sekedar bertentangan dengan hukum yang tertulis tetapi juga bertentangan dengan hukum yang tidak tertulis. Meskipun unsur melawan hukum di luar undang-undang diakui, dalam praktiknya, sifat melawan hukum materiil masih dibagi lagi menjadi sifat melawan hukum dalam fungsi negatif dan sifat melawan hukum dalam fungsi positif. ${ }^{23}$ Sifat melawan hukum materiil dalam fungsi negatif berarti meskipun perbuatan memenuhi unsur delik tetapi tidak bertentangan dengan rasa keadilan masyarakat, maka perbuatan tersebut tidak dipidana. Hal sebaliknya pada melawan hukum dalam fungsi positif.

\section{c. Sifat hukum pidana bersifat publik dan hukum perdata bersifat privat}

Persekongkolan tender dalam pandangan hukum persaingan usaha, perlu memperhatikan perbuatan persaingan usaha tidak sehat yang berkaitan dengan perilaku yang dilakukan dengan cara melawan hukum. Persaingan usaha yang melawan hukum adalah segala kegiatan usaha yang melawan larangan undangundang. Larangan undang-undang adalah setiap ketentuan dalam undangundang yang melarang perilaku tertentu dan secara imperatif. Sifat larangan dalam suatu ketentuan sering dapat disimpulkan dari formulasi ketentuan yang bersangkutan. Misalnya kata dilarang atau tidak boleh menunjukkan adanya ketentuan larangan. Ketentuan larangan-larangan sering diatur dalam ketentuan pidana, tetapi tidak hanya terbatas dalam aturan pidana. Apabila ketentuan undang-undang tidak jelas, maka perlu interpretasi untuk menentukan apakah ketentuan tersebut mengizinkan atau melarang perilaku tertentu. ${ }^{24}$

Dalam persekongkolan tender perumusan melawan hukum memiliki makna yang penting, khususnya dalam ranah hukum pidana guna memberikan batasan ruang lingkup rumusan delik yang dapat sangat luas. Schaffmeister menyatakan perumusan melawan hukum menjadi penting jika suatu perilaku yang secara

${ }^{23}$ Eddy O.S. Hiariej, Prinsip-Prinsip Hukum Pidana, Cahaya Atma Pustaka, Yogyakarta, 2014, hlm. 199.

${ }^{24}$ Knud Hansen et. al., Undang-Undang Larangan Monopoli dan Persaingan Usaba Tidak Sehat, Katalis, Jakarta, 2001, hlm. 68 
formal dapat dirumuskan dalam ruang lingkup rumusan delik, namun secara umum sebenarnya bukan merupakan tindak pidana, maka syarat melawan hukum dijadikan satu bagian dari rumusan delik. Tanpa ditambahkannya perkataan melawan hukum mungkin timbul bahaya, yaitu mereka yang menggunakan haknya akan termasuk ke dalam ketentuan undang-undang pidana. ${ }^{25}$

Persinggungan "melawan hukum" dalam konteks hukum pidana dengan dalam konteks hukum perdata berpangkal dari perbedaan sifat hukum pidana yang bersifat publik dan hukum perdata yang bersifat privat, sebagaimana pendapat berikut:26

“Hanya saja yang membedakan antara perbuatan (melawan hukum) pidana dengan perbuatan melawan hukum (perdata) adalah bahwa sesuai dengan sifatnya sebagai hukum publik, maka dengan perbuatan pidana, ada kepentingan umum yang dilanggar (di samping mungkin juga kepentingan individu), sedangkan dengan perbuatan melawan hukum (perdata) maka yang dilanggar hanya kepentingan pribadi saja."

\section{Batasan melawan hukum dalam hukum perdata dan pidana dalam putusan tender}

Selama praktik penegakan Undang-Undang No. 5 Tahun 1999 terdapat kasuskasus dugaan persekongkolan tender yang penyelesaiannya dilakukan berdasarkan Undang-Undang No. 5 Tahun 1999 maupun Undang-Undang No. 31 Tahun 1999 juncto Undang-Undang No. 20 Tahun 2001 dengan hasil yang berbedabeda. Misalnya kasus persekongkolan tender penjualan dua kapal tanker VLCC

\footnotetext{
${ }^{25}$ Schaffmeister dalam Chairul Huda, Dari Tiada Pidana Tanpa Kesalahan Menuju kepada Tiada Pertanggungjawban Pidana Tanpa Kesalaban, Kencana, Jakarta, 2006, hlm. 50. 22.

${ }^{26}$ Munir Fuady. Perbuatan Melawan Hukum (Pendekatan Kontemporer), Citra Aditya Bakti, Bandung, 2005, hlm.
} 
No. Hull 1540 dan 1541,27 pelaksanaan tender Indomobil pada 30 Mei 2002,28 pengadaan tinta pemilu legislatif tahun $2004,{ }^{29}$ dan KTP elektronik. ${ }^{30}$

Kasus persekongkolan tender pengadaan barang/jasa oleh pemerintah menyangkut kepentingan publik. Kecenderungan yang terjadi dalam proses tender adalah upaya untuk mengakomodasi kepentingan pihak-pihak tertentu sehingga menghasilkan keputusan yang merugikan pihak-pihak lainnya dalam proses tender. Akomodasi kepentingan dapat bermanifestasi dalam bentuk praktik korupsi atau penyuapan, kolusi, nepotisme atau kroniisme yang memberikan keistimewaan atau privilege kepada pihak tertentu untuk memenangkan tender yang dilaksanakan. ${ }^{31}$ Ketika praktik-praktik semacam itu terjadi, maka aturan dalam hukum pidana perlu ditegakkan.

\section{a. Kasus Indomobil}

Perkara No. 03/KPPU-I/2002 tentang Tender Penjualan Saham dan Obligasi (convertible bonds PT Holdiko Perkasa dan convertible bonds Badan Penyehatan Perbankan Nasional atau BPPN) PT Indomobil Sukses Internasional, Tbk (PT IMSI). Penjualan saham PT IMSI dilakukan dalam jangka waktu pelaksanaan yang terlalu singkat, diikuti oleh peserta dengan jumlah yang terbatas, harga jual yang terlalu rendah serta adanya dugaan pelanggaran prosedur dan persekongkolan dalam transaksi senilai Rp 625 miliar yang dimenangkan oleh PT Cipta Sarana Duta Perkasa (CSDP). ${ }^{32}$

Persekongkolan antara lain dilakukan melalui tindakan penyesuaian (concerted action) yang dilakukan oleh peserta tender setidak-tidaknya oleh PT Alpha Sekuritas Indonesia (ASI) dan PT CSDP. Hal tersebut berdasarkan temuan dokumen tender yang mirip (cover letter dan usulan mark up CSPLTA), ${ }^{33}$ serta pemberian kesempatan eksklusif oleh penyelenggara tender atau pihak terkait secara langsung maupun tidak langsung kepada pelaku usaha yang mengikuti

${ }^{27}$ Putusan KPPU No. 07/KPPU-L/2004 Tender Penjualan Dua Unit Tanker Pertamina.

28Putusan KPPU No. 03/KPPU-I/2002 Tender Penjualan Saham PT Indomobil Sukses International. Putusan KPPU ini dibatalkan oleh Pengadilan Negeri, selanjutnya KPPU mengajukan kasasi ke Mahkamah Agung (MA). Putusan MA ini menarik, karena membatalkan Putusan Pengadilan Negeri dan Putusan KPPU. MA menilai pengadilan negeri salah menerapkan hukum, yaitu ada kesalahan prosedural. Tapi di sisi lain, putusan KPPU juga cacat yuridis, karena putusan KPPU memakai irah-irah seolah-olah KPPU adalah badan peradilan. www.hukumonline.com/berita/baca/hol7230/soal-tender-indomobil-ma-batalkan-putusan-pn-dan-kppu, "Soal Tender Indomobil MA Batalkan Putusan Putusan PN dan KPPU," 16 Januari 2003.

${ }^{29}$ Putusan KPPU No. 08/KPPU-L/2004 Dugaan Persekongkolan Pengadaan Tinta Sidik Jari Pemilu Legislatif Tahun 2004.

${ }^{30}$ Putusan KPPU No. 03/KPPU-L/2012 Tender Penerapan Kartu Tanda Penduduk Berbasis NIK Secara Nasional (KTP Elektronik) Tahun 2011 s/d 2012 tanggal 13 November 2012.

${ }^{31}$ Mohammad Yusuf Adidana, "Persekongkolan Tender sebagai Suatu Tindakan yang Anti Persaingan Sehat," www.hukumonline.com/berita/baca/hol18357/persekongkolan-tender-sebagai-suatu-tindakan-yanganti-persaingan-sehat, Akses 22 September 2017.

${ }^{32}$ Anonim, "Mengurai Benang Kusut Tender Indomobil, "www.hukumonline.com/ berita/baca/hol5719/mengurai-benang-kusut-tender-indomobil, Akses 21 Februari 2017.

${ }^{33}$ Ibid. 
tender dengan cara melawan hukum. ${ }^{34}$ Selain itu, ditemukan pula kesamaan perilaku peserta tender dengan mengajukan ditiadakannya bid deposit sebesar Rp 50 miliar, account pembayaran bid deposit, material threshold, serta tidak menyebutkan keanggotaan konsorsiumnya. Keterlibatan pihak penjual dalam hal ini BPPN dan PT Holdiko Perkasa serta konsultannya Deloitte Touche \& Tohmatsu (DTT) juga dibuktikan oleh KPPU.

Dalam pertimbangan majelis, tindakan persekongkolan tender penjualan saham PT IMSI telah terbukti secara sah dan meyakinkan telah menghambat persaingan dalam bentuk tidak adanya persaingan harga dan/atau persaingan jumlah dan kualitas peserta dan/atau persaingan pemenuhan persyaratan tender. Persekongkolan yang telah terjadi dalam tender penjualan saham PT IMSI tidak mungkin terjadi kalau pihak penjual tidak ikut terlibat atau setidaktidaknya membantu prosesnya. Oleh karena itu atas kerugian negara, tidak sepenuhnya kesalahan dibebankan pada pihak pembeli. Majelis Komisi berharap kesalahan yang dilakukan oleh para pejabat BPPN diusut oleh pihak yang berwenang. 35

Pertimbangan majelis hakim terkait dengan makna "melawan hukum" tidak dijelaskan secara eksplisit. Namun, bila didasarkan pada fakta dan bukti persidangan maksud dari "melawan hukum" dapat diartikan sebagai perbuatan atau tindakan yang dilakukan bertentangan dengan hukum yaitu bertentangan dengan Undang-Undang No. 5 Tahun 1999. Namun, untuk membuktikan terpenuhinya unsur persaingan tidak sehat, Majelis Komisi mendasarkan pada tindakan para terlapor yang "menghambat persaingan", bukan pada aspek "melawan hukum."36 Penjelasan aspek melawan hukum dalam ranah perdata ini juga tidak dapat ditemukan di dalam putusan keberatan di Pengadilan Negeri dan kasasi oleh Mahkamah Agung. Bahkan, Mahkamah Agung membatalkan putusan KPPU tanpa masuk ke pokok perkaranya. ${ }^{37}$ Menurut Mahkamah Agung, putusan KPPU cacat formil sehingga putusannya batal demi hukum.

Di sisi lain, aspek pidana kasus persekongkolan tender PT Indomobil berhenti pada tahap penyelidikan sebab pihak kejaksaan agung belum menemukan adanya

${ }^{34}$ Peraturan KPPU No. 2 Tahun 2010.

${ }^{35}$ Putusan KPPU No. 03/KPPU-I/2002.

${ }^{36}$ Ibid., hm. 97.

${ }^{37}$ Anonim, "Soal tender Indomobik MA Batalkan putusan PN dan KPPU," www.hukumonline.com/berita/baca/hol7230/soal-tender-indomobil-ma-batalkan-putusan-pn-dan-kppu, Akses 22 September 2017. 
indikasi perbuatan melawan hukum. ${ }^{38}$ Bila dirunut dari keterangan pers jaksa agung, terdapat perbedaan antara hasil temuan KPPU dan penyelidikan oleh kejaksaan agung. ${ }^{39}$ Berangkat dari perbedaan kesimpulan antara kejaksaan dengan KPPU, tindakan menghambat persaingan seolah-olah bukan merupakan tindakan melawan hukum dari sudut pandang pidana. Hasil penyelidikan pihak kejaksaan menyimpulkan bahwa tindakan menghambat persaingan tidak masuk dalam klasifikasi sifat melawan hukum dari kacamata pidana.

\section{b. Kasus Kapal Tanker VLCC (Very Large Crude Carrier)}

Kasus ini terkait dengan proses penjualan 2 (dua) unit Tanker Very Large Crude Carrier (VLCC) No. Hull 1540 dan 1541 milik PT Pertamina Persero, ${ }^{40}$ yang dilakukan melalui persekongkolan untuk mengatur pemenang tender. ${ }^{41}$ Para terlapor dalam perkara ini adalah PT Pertamina Persero (Terlapor I); Goldman Sachs (Singapore). Pte (Terlapor II); Frontline, Ltd. (Terlapor III); PT Corfina Mitrakreasi (Terlapor IV); PT Perusahaan Pelayaran Equinox (Terlapor V). Berdasarkan Putusan KPPU No. 07/KPPU-L/2004, Majelis Komisi membuktikan tindakan para pihak (PT Pertamina, Goldman Sachs Pte., dan Frontline Ltd.) adalah melawan hukum dan memenuhi unsur persaingan usaha tidak sehat berdasarkan Pasal 19 huruf d dan 22 Undang-Undang No. 5 Tahun 1999. Majelis Komisi tidak menjabarkan makna "melawan hukum" menurut ketentuan hukum persaingan usaha (Undang-Undang No. 5 Tahun 1999) atau KUHPerdata. Majelis Komisi menyebutkan tindakan para terlapor dilakukan secara melawan hukum, antara lain: penunjukan langsung tanpa melalui proses tender, dan penerimaan/penyerahan (bid) yang tidak sesuai dengan ketentuan bid yang telah dikeluarkan oleh penyelenggara tender yang telah diberi kewenangan. Majelis Komisi menyatakan bahwa kedua tindakan itu menghambat persaingan usaha dan menyertakan alasannya namun tidak jelas mengapa tindakan tersebut melawan hukum. ${ }^{42}$

Majelis hakim memutuskan bahwa PT Pertamina Persero terbukti melanggar Pasal 19 huruf d Undang-Undang No. 5 Tahun 1999 dalam hal penunjukkan langsung Goldman Sachs, Pte. sebagai financial advisor dan arranger. Majelis hakim selanjutnya memutuskan PT Pertamina Persero dan Goldman Sachs terbukti melanggar Pasal 19 huruf d Undang-Undang No. 5

\footnotetext{
${ }^{38}$ www.kompas.com/kompas-cetak/0208/31/ekonomi/keja13.htm per 31 Agustus 2002, sebagaimana dikutip dari www.unisosdem.org/article_printfriendly.php?aid=480\&coid=2\&caid=30, "Kejagung hentikan penyelidikan Indomobil,” Akses 22 September 2017.

${ }^{39}$ Anonim, "Lanjutan kasus tender Indomobil di Kejagung tergantung ekspose," www.hukumonline.com/berita/baca/hol5693/lanjutan-kasus-tender-indomobil-di-kejagung-tergantung-ekspose, Akses 22 September 2017.

${ }^{40}$ Proses penjualan ini kemudian disebut sebagai divestasi VLCC.

${ }^{41}$ Putusan KPPU No. 07/KPPU-L/2004 Tender Penjualan Dua Unit Tanker Pertamina.

${ }^{42}$ Ketidakjelasan ini menjadi dasar pembelaan PT Petamina dan terlapor lainnya pada tingkat Peninjauan Kembali ke Mahkamah Agung. Mereka mengelak telah melakukan perbuatan melawan hukum sebab Putusan KPPU tersebut tidak menguraikan tentang perbuatan melawan hukum. Putusan No. 01 PK/Pdt.Sus/2007, Op. Cit., hlm. 125.
} 
Tahun 1999 dalam hal penerimaan penawaran (bid) ketiga dari Frontline, Ltd. Kemudian majelis hakim juga menyatakan bahwa PT Pertamina Persero, Goldman Sachs, Frontline Ltd, dan PT Equinox terbukti melanggar Pasal 22 Undang-Undang No. 5 Tahun 1999 atas persekongkolan yang dilakukan.

Putusan Peninjauan Kembali Majelis Mahkamah Agung yang menganulir putusan KPPU juga tidak mendasarkan pertimbangannya pada aspek melawan hukum. Tidak jelas apakah putusan KPPU telah keliru menginterpretasikan perbuatan melawan hukum karena dalam Putusan Peninjauan Kembali, Mahkamah Agung menguraikan pertimbangannya berdasarkan pada unsurunsur lain di luar unsur persaingan usaha tidak sehat, khususnya aspek melawan hukum. ${ }^{33}$

Mahkamah Agung juga membatalkan putusan KPPU yang menyatakan adanya kerugian negara yang disebabkan oleh perkara tender ini, justru negara diuntungkan. Terlepas dari unsur politik di balik kasus ini, putusan peninjauan kembali diindikasi kuat sebagai salah satu alasan disetujuinya SP3 oleh Jaksa Agung. Meskipun dalam penjelasannya Jaksa Agung menyatakan adanya unsur melawan hukum dalam kasus ini, ${ }^{44}$ terhentinya perkara ini pada tahap penyelidikan menjadikan peneliti tidak dapat menganalisis aspek melawan hukum dalam putusan pengadilan. Sikap kejaksaan agung tersebut tidak tepat. Bila kejaksaan agung menganggap ada unsur melawan hukum dalam kasus tersebut, seharusnya justru membawanya ke persidangan, dan hakimlah yang memutuskan apakah memang semua unsur tindak pidana terpenuhi atau tidak. ${ }^{45}$

Berdasarkan analisis di atas, dapat disimpulkan bahwa putusan perdata dapat mempengaruhi proses pidana pada kasus persekongkolan tender yang melibatkan pihak yang sama. Meskipun demikian, belum dapat dinyatakan secara tegas bahwa putusan perdata, dalam hal ini putusan KPPU, yang menyatakan adanya perbuatan melawan hukum dapat menjadi dasar terpenuhinya unsur melawan hukum dari sudut pandang pidana.

\footnotetext{
${ }^{43}$ Ibid, hlm. 314.

${ }^{44}$ www.hukumonline.com/berita/baca/hol21050/sp3-vlcc-disetujui-jaksa-agung (Loc. Cit.)

${ }^{45}$ Kejaksaan Agung, menyatakan penghentian penyidikan karena, tidak dapat dibuktikan adanya kerugian negara, karena Badan Pemeriksa Keuangan (BPK) belum dapat menghitung kerugian negara, sebab penghitungan kerugian negara atas transaksi penjualan VLCC tidak dapat dilakukan sesuai dengan metode dan prosedur penghitungan yang diterapkan oleh BPK RI. BPK menyatakan tidak berkompeten untuk menilai dan menetapkan harga pasar yang wajar dalam transaksi penjualan 2 unit VLCC Pertamina. Pihak Kejaksaan Agung dapat saja menyewa lembaga appraisal yang kompeten untuk melakukan penilaian harga pasar yang wajar sebagai dasar dalam menentukan kerugian negara. http://www.bpk.go.id/assets/files/attachments/2009/02/sp-vlcc.pdf Sayang pihak Kejaksaan Agung, tidak melaksanakan hal tersebut.
} 


\section{c. Kasus Pengadaan Tinta Pemilu 2004}

Pengadaan tinta pemilu tahun 2004 dinyatakan telah melanggar Pasal 22 Undang-Undang No. 5 Tahun 1999 oleh KPPU. KPPU menjatuhkan denda kepada sembilan terlapor yaitu $\mathrm{Rp} 2.159 .233 .800,00.46$ Denda tersebut dibebankan secara tanggung renteng. Para terlapor dari kasus ini adalah Konsorsium PT Mustika Indra Mas, Konsorsium PT Multi Mega Service, Konsorsium PT Senorotan Perkasa, Konsorsium PT Tricipta Adimandiri, Konsorsium PT Yanaprima Hastapersada, Prof. Dr. Rusadi Kantaprawira (ketua panitia pengadaan tinta sidik jari), Konsorisum PT Fulcomas Jaya, Konsorsium PT Wahgo International Corporation, Konsorsium PT Lina Permai Sakti, dan PT Nugraha Karya Oshinda. Putusan KPPU dikuatkan oleh Putusan Mahkamah Agung pada tingkat Kasasi No. 05K/KPPU/2006 tanggal 19 Mei 2008 dan Putusan Peninjauan Kembali No. 25/PK/Pdt.sus-KPPU/2017.

Terdapat dua penyimpangan dalam kasus ini yaitu mengenai pemenangan tender dan penetapan harga. ${ }^{47}$ Pada saat itu, regulasi yang berlaku terkait pengadaan barang/jasa adalah Keppres No. 80 Tahun 2003 tentang Pedoman Pelaksanaan Pengadaan Barang/Jasa yang mengatur bahwa hanya terdapat satu pemenang tender. Namun, dalam kasus ini ditetapkan pemenang tender secara multiwinner. Terdapat pula penyimpangan penetapan harga terlihat dari adanya empat pemegang tender yang memiliki harga sama. Harga tinta lokal disamaratakan. Selain itu, dapat dibuktikan bahwa penetapan harga bukan berdasarkan harga penawaran terendah meskipun terdapat peserta tender yang menawarkan harga lebih rendah namun panitia justru memilih harga yang lebih tinggi.

Berbeda dengan Putusan KPPU, justru di dalam putusan pidana korupsi yang melibatkan salah satu panitia pengadaan tinta pemilu 2004 ini Mahkamah Agung menguraikan secara gamblang makna perbuatan melawan hukum yang tercantum dalam Pasal 2 ayat (1) Undang-Undang No. 31 Tahun 1999 juncto Undang-Undang No. 20 Tahun 2001 tentang Pemberantasan Tindak Pidana Korupsi. Dalam Putusan No. 2608 K/Pid/2006 tanggal 21 Februari 2007, Mahkamah Agung memaknai perbuatan melawan hukum dalam arti luas yaitu mempertimbangkan aspek formil dan materiilnya, dan mengenai perbuatan melawan hukum dalam arti materiil yang meliputi fungsi positif dan negatifnya.

Dalam menyatakan pelanggaran Pasal 22 Undang-Undang No. 5 Tahun 1999 terhadap para terlapor kasus pengadaan tinta sidik jari untuk pemilu legislatif 2004, KPPU sama sekali tidak menyinggung unsur melawan hukum atau menghambat persaingan usaha sebagai unsur dari persaingan usaha tidak sehat.

\footnotetext{
${ }^{46}$ Anonim, "Pengadaan Tinta Pemilu Juga Melanggar UU Anti Monopoli", www.hukumonline.com/berita/baca/hol13157/pengadaan-tinta-pemilu-juga-melanggar-uu-anti-monopoli, Akses 5 Maret 2017.

${ }^{47}$ Anonim "Ada 2 Penyipangan Pengadaan Tinta Pemilu," news.detik.com/berita/570691/ada-2penyimpangan-pengadaan-tinta-pemilu, Akses 5 Maret 2017.
} 
Dalam Putusan No. 08/KPPU-L/2004 tersebut, hanya ditegaskan bentuk praktik persaingan usaha tidak sehat dan persekongkolan, antara lain: pembuatan Nota Kesepahaman antar pemasok tinta di Komisi Pemilihan Umum (KPU); penunjukan perusahaan yang tidak berkemampuan, perubahan harga penawaran secara ilegal; dan perjalanan beberapa pejabat KPU ke China yang dibiayai oleh rekanan.48 Selebihnya, KPPU hanya menguraikan kronologis dan tindakan-tindakan para terlapor untuk kemudian dijerat Pasal 22 Undang-Undang No. 5 Tahun 1999 dan menyinggung adanya kerugian negara yang diakibatkan oleh tindakan-tindakan tersebut.

Kasus ini diputus oleh Mahkamah Agung setelah putusan Mahkamah Konstitusi (MK) yang menyatakan bahwa Penjelasan Pasal 2 ayat (1) UndangUndang No. 20 Tahun 2001 juncto Undang-Undang No. 31 Tahun 1999 bertentangan dengan Undang-Undang Dasar Republik Indonesia Tahun 1945 (UUD 1945) dan telah pula dinyatakan tidak mempunyai kekuatan hukum mengikat. ${ }^{49}$ Mahkamah Konstitusi berpendirian bahwa konsep melawan hukum materiil (materiele wederrechtelijkheid) dengan titik tolak pada hukum tidak tertulis dalam ukuran kepatutan, kehati-hatian dan kecermatan yang hidup dalam masyarakat, sebagai satu norma keadilan memiliki ukuran yang tidak pasti, dan berbeda-beda dari satu lingkungan masyarakat tertentu kelingkungan masyarakat lainnya. Putusan korupsi tinta pemilu 2004 ini, kembali Mahkamah Agung, menerapkan sifat melawan hukum materiil sebagai fungsi positif. ${ }^{50}$

\section{d. Kasus Kartu Tanda Penduduk Elektronik (e-KTP)}

Kasus ini merupakan pengadaan paket e-KTP berbasis No. Induk Kependudukan Nasional Periode 2011-2012 di Kementerian Dalam Negeri salah satu kasus yang ditangani oleh KPPU dan selanjutnya diproses oleh KPK sebagai perkara korupsi.

Pihak yang diperiksa oleh KPPU adalah Panitia Tender/Pelelangan Penerapan KTP Berbasis NIK Nasional (KTP Elektronik) Tahun 2011-2012, Konsorsium PNRI, PT Astragraphia, Tbk, PT Kwarsa Hexagon, Terlapor V, PT

${ }^{48}$ Putusan KPPU No. 08/KPPU-L/2004, butir 1.

${ }^{49}$ Putusan Mahkamah Konstitusi No. 003/PUU-IV/2006 tanggal 25 Juli 2006.

${ }^{50}$ Putusan MA No. 275 K/Pid/1983 tanggal 29 Desember 1983 atas nama terdakwa Drs R.S. Natalegawa (kemudian diikuti pula dalam Putusan Mahkamah Agung No. 2477 K/Pid/1988 tanggal 23 Juli 1993, Putusan Mahkamah Agung No. 1571 K/Pid/1993 tanggal 18 Januari 1995) 
Trisakti, Mustika Grafika dan PT Sumber Cakung yang diduga melanggar Pasal 22 Undang-Undang No. 5 Tahun 1999.

Putusan KPPU No. 03/KPPU-L/2012 tanggal 13 November 2012, menyatakan Panitia Tender/Pelelangan (KTP Elektronik) Tahun 2011-2012, Konsorsium PNRI, PT Astragraphia,Tbk terbukti melanggar ketentuan Pasal 22 Undang-Undang No. 5 Tahun 1999 dan menjatuhkan denda kepada Konsorsium PNRI sebesar Rp 20 Milyar dan PT Astragraphia,Tbk sebesar Rp 4 Milyar. Putusan KPPU No. 03/KPPU-L/2012 diajukan keberatan kepada Pengadilan Negeri. Pengadilan Negeri Jakarta Pusat mengabulkan keberatan yang diajukan Konsorsium PNRI dan PT Astragraphia melalui Putusan Pengadilan Negeri Jakarta Pusat No. 558/KPPU.G/2012/PN.Jkt.Pst. atas putusan tersebut KPPU mengajukan Kasasi ke Mahkamah Agung, namun tidak dapat diterima berdasarkan Putusan No. 55 K/Pdt.Sus-KPPU/2014.

Perkara KTP elektronik, diproses oleh KPK, dengan menetapkan beberapa tersangka, dan diteruskan sampai tahap persidangan yang dipisah menjadi beberapa perkara. Salah satu perkara KTP elektronik yang telah diputus adalah terhadap terdakwa mantan Direktur Jenderal Kependudukan dan Catatan Sipil Kemendagri, Irman, dan mantan Direktur Pengelola Informasi Administrasi Kependudukan Ditjen Dukcapil Kemendagri sekaligus Pejabat Pembuat Komitmen, Sugiharto, yang didakwa dengan Pasal 2 ayat (1) atau Pasal 3 Undang-Undang No. 31 Tahun 1999 sebagaimana telah diubah dengan UndangUndang No. 20 Tahun 2001 tentang Pemberantasan Tindak Pidana Korupsi juncto Pasal 55 ayat (1) angka 1 KUHP. Putusan hakim pada perkara No. 41/Pid.Sus/TPK/2017/PN.Jkt.Pst menyatakan kedua terdakwa bersalah dan dipidana dengan pidana penjara 7 tahun. ${ }^{51}$

Perkara pidana terhadap Irman dan Sugianto Putusan Pengadilan Tindak Pidana Korupsi No. 41/Pid.Sus/TPK/2017/PN.Jkt.Pst menyatakan kedua terdakwa terbukti melakukan penyalahgunaan wewenang, ${ }^{52}$ Hakim menyatakan "Telah terjadi kolusi yang dilakukan terdakwa Irman dan terdakwa Sugiharto, Diah Anggraini, Andi Agustinus, peserta lelang menggunakan konsorsium tertentu," hakim menegaskan terjadi pemberian dan penerimaan uang mulai dari proses penganggaran dan lelang yang bertujuan agar pihakpihak tertentu menjadi pemenang dengan cara yang tidak benar.

Hakim menyatakan "Terhadap item barang yang akan diadakan telah diarahkan menggunakan produk tertentu sehingga tidak terjadi kompetisi yang sehat dalam pelaksanaan pengadaannya dari segi mutu dan harga," Penyimpangan ini ditegaskan majelis hakim bertentangan dengan prinsip pengadaan barang dan jasa pemerintah yakni efsien, efektif, transparan, terbuka dan akuntabel. Hakim juga berkeyakinan "Terdakwa Irman pada proyek e-KTP selaku dirjen Dukcapil sesungguhnya berada di luar struktur proyek, tetapi berdasarkan uraian fakta (terdapat) peran terdakwa dalam menentukan pemenang yang akan mengerjakan proyek, terdakwa juga menerima sejumlah

${ }^{51}$ Perkara pidana ini belum memiliki kekuatan hukum tetap karena masih dalam proses banding di Pengadilan Tinggi, atas permohonan banding KPK.

${ }^{52}$ Penyalahgunaan wewenang merupakan bentuk khusus dari perbuatan melawan hukum, artinya dengan terbukti adanya penyalahgunaan mewenang maka perbuatan melawan hukum telah dilakukan. 
uang. Perbuatan terdakwa Irman melampaui batas kewenangan," sedangkan "Perbuatan terdakwa Sugiarto sebagai pejabat pembuat komitmen dalam proyek e-KTP telah dilaksanakan dengan tidak memenuhui ketentuan pengadaan barang dan jasa pemerintah. Telah melanggar etika pengadaan antara lain menjaga kerahasaian dokumen pengadaan barang dan jasa, mempengaruhi terjadinya persaingan tidak sehat." 53

Menarik pandangan hakim pidana yang menegaskan penyalahgunaan wewenang yang bermakna terjadi perbuatan melawan hukum yang dilakukan terdakwa telah menjadikan pengadaan proyek e-KTP sebagai persaingan tidak sehat. Hal ini bertolak belakang dengan pandangan komisioner KPPU yang memeriksa perkara kasus e-KTP, dimana terdapat disenting opinion, yang menyatakan tidak ada persekongkolan tender. Pendapat yang berbeda dari komisioner tersebut, diperhatikan oleh Majelis Pengadilan Negeri Jakarta Pusat dan Mahkamah Agung, yang membatalkan Putusan KPPU.

Berdasarkan putusan KPPU yang telah dianalisis sebelumnya, unsur penentu terpenuhinya pasal persekongkolan tender di Undang-Undang No. 5 Tahun 1999 dapat diukur dari: apakah perbuatan tersebut anti-persaingan, dan apakah perbuatan tersebut merugikan kepentingan umum. Dengan kata lain, unsur melawan hukum tidak menjadi ukuran utama dalam kasus persekongkolan tender. Terlebih lagi, dalam menguraikan unsur-unsur Pasal 22 Undang-Undang No. 5 Tahun 1999, KPPU seringkali menerapkan pendekatan per se illegal daripada pendekatan rule of reason. Hal ini bertolak belakang dengan rumusan Pasal 22 yang menggunakan pendekatan rule of reason. Meskipun terjadi paradoks di lapangan, kedua pendekatan ini mempunyai tujuan akhir yang sama, yaitu untuk menindak perilaku yang menghambat persaingan demi menjamin terpenuhinya kepentingan masyarakat.

Selain itu, sebagaimana rumusan Pasal 1 angka 6 Undang-Undang No. 5 Tahun 1999, terdapat tiga kriteria tindakan pelaku usaha yang dapat digunakan untuk memenuhi unsur persaingan usaha tidak sehat, yaitu: cara tidak jujur atau melawan hukum atau menghambat persaingan usaha. Digunakannya kata "atau"

53 Rina Atriana, "Vonis e-KTP, Hakim: Irman-Sugiharto Terbukti Salahgunakan Wewenang" https:// news.detik.com/berita/d-3567145/vonis-e-ktp-hakim-irman-sugiharto-terbukti-salahgunakanwewenang, Akses 12 Oktober 2017. 
menunjukkan bahwa kriteria ini bersifat alternatif, artinya satu kriteria saja cukup untuk membuktikan terpenuhinya unsur persaingan usaha tidak sehat. Konsekuensi logis dari penggunaan kata "atau" dalam rumusan pasal ini ialah istilah melawan hukum bersifat ekuivalen dengan istilah menghambat persaingan. Dengan kata lain, jika suatu tindakan memenuhi sub-unsur menghambat persaingan, maka tindakan tersebut sudah dianggap sebagai perbuatan melawan hukum dari perspektif hukum persaingan usaha. Dengan demikian, dasar hukum terpenuhinya unsur persekongkolan tender dalam hukum perdata memiliki batas yang luas sekali. Akibatnya, hal ini seringkali menjadi dasar pihak yang berkeberatan dengan putusan KPPU untuk mengajukan keberatan ke Pengadilan Negeri hingga ke tahap Peninjauan Kembali kepada Mahkamah Agung.

Di lapangan hukum pidana, persekongkolan tender barang/jasa pemerintah seringkali berkaitan dengan tindak pidana korupsi yang sudah diatur dalam Undang-Undang No. 31 Tahun 1999 juncto Undang-Undang No. 21 Tahun 2001 tentang Pemberantasan Tindak Pidana Korupsi (Undang-Undang Tipikor), khususnya Pasal 2 ayat (1). Terdapat dua unsur pasal tersebut yang sering menjadi rujukan utama apakah suatu persekongkolan tender memiliki dimensi korupsi, yaitu apakah perbuatan tersebut melawan hukum, dan apakah perbuatan tersebut merugikan keuangan negara. Biasanya, unsur merugikan keuangan negara sudah dinyatakan terlebih dahulu dalam putusan KPPU untuk kemudian ditindaklanjuti oleh aparat negara yang berwenang menangani kasus tindak pidana korupsi.

Berbeda dengan Undang-Undang No. 5 Tahun 1999, unsur melawan hukum dalam Undang-Undang Tipikor merupakan unsur yang tercantum dalam delik formil. Hal ini berarti perbuatan pihak-pihak yang dinilai KPPU telah melanggar larangan Undang-Undang No. 5 Tahun 1999 harus terbukti memenuhi unsur melawan hukum sebagaimana diatur dalam Undang-Undang Tipikor. Berdasarkan hasil analisis kasus perkara korupsi tender PT Indomobil, kapal tanker VLCC dan tinta pemilu legislatif 2004, ketiganya memiliki hasil yang berbeda-beda. Untuk kasus persekongkolan tender PT Indomobil berhenti pada tahap penyelidikan sebab pihak kejaksaan belum menemukan adanya indikasi perbuatan melawan hukum. Berangkat dari perbedaan hasil penyelidikan antara kejaksaan dengan KPPU kemudian menimbulkan tanya; apakah tindakan 
menghambat persaingan bukan merupakan tindakan melawan hukum dari sudut pandang pidana? Bila ditarik lagi pertanyaanya agar lebih konkrit: apakah tindakan persekongkolan tender yang dilarang dalam Undang-Undang No. 5 Tahun 1999 dapat diklasifikasikan sebagai melawan hukum (dalam hukum pidana)? Di Amerika Serikat, dan Jepang, persekongkolan tender jelas merupakan perbuatan melawan hukum (illegal/unlawful act). ${ }^{54}$ Sedangkan di Indonesia, aspek pidana persekongkolan tender tidak diatur di dalam KUHP atau suatu hukum khusus. Larangan dan sanksi persekongkolan tender diatur dalam Undang-Undang No. 5 Tahun 1999 Pasal 22 dengan sanksi pidananya pada Pasal 48 ayat (2).

Kembali pada makna sifat melawan hukum sebagai pelanggaran terhadap kaidah undang-undang atau kepentingan hukum yang disebut dalam undangundang (onwetmatige daad), maka tindakan persekongkolan tender seharusnya memenuhi pengertian melawan hukum dalam hukum pidana. ${ }^{55}$ Begitu pula jika kita merujuk kembali pernyataan dissenting opinion Hakim Agung Rehngena Purba, yang menyatakan bahwa penunjukkan langsung yang melanggar ketentuan pedoman pelaksanaan pengadaan barang/jasa adalah tindakan melawan hukum, maka sudah seharusnya perbuatan persekongkolan tender yang dinyatakan telah sah memenuhi unsur Pasal 22 Undang-Undang No. 5 Tahun 1999 merupakan perbuatan melawan hukum.

Penjelasan komprehensif mengenai aspek melawan hukum dalam tindak pidana korupsi perkara tender terdapat dalam Putusan Mahkamah Agung No. 2608 K/Pid/2006 tanggal 21 Februari 2007 atas terdakwa Achmad Rojadi S.Sos. Menurut Mahkamah Agung, terpenuhinya sifat melawan hukum tidak hanya berdasarkan pada undang-undang, tetapi juga pada rasa keadilan di masyarakat. Mahkamah Agung berpegang pada penjelasan Pasal 2 ayat (1) Undang-Undang Tipikor yang menganut ajaran sifat melawan hukum materiil dalam fungsinya

${ }^{54} \mathrm{Di}$ Jepang, karakteristik persekongkolan tender yang paling jelas dalam industri konstruksi adalah keterlibatan asosiasi perdagangan dalam menentukan pemenang kontrak dan harga penawaran yang telah diatur. Di AS, persekongkolan tender terjadi melalui adanya kartel, yang merupakan larangan per se ilegal. Meskipun metode yang digunakan oleh para kontraktor di AS untuk berkoordinasi hampir sama dengan kasus persekongkolan tender di Jepang, namun politisi dan institusi pemerintah tidak memiliki banyak andil. OECD, Guidelines for Fighting Bid Rigging in Public Procurement, Helping Governments to Obtain Best Value for Money, hlm. 15. Naoaki Okatanit, "Regulations on Bid Rigging in Japan, the United States and Europe Pacific Rim," Law \& Policy Journal, Vol. 4 No. I, 1995, hlm. 260.

${ }^{55}$ Andi Hamzah, Asas-Asas Hukum Pidana, Edisi Revisi, Rineka Cipta, Jakarta, 2008, hlm. 5-14. 
yang positif, dengan kriteria bahwa perbuatan yang tidak diatur dalam perundangundangan $i^{56}$ dipandang sebagai perbuatan tercela karena tidak sesuai dengan rasa keadilan atau norma-norma kehidupan sosial dalam masyarakat.

Dalam hukum pidana, khususnya terhadap perkara tindak pidana korupsi, telah terjadi pergeseran dalam praktik di pengadilan dimana melawan hukum formal (formele wederrechtelijkheid) bukanlah unsur mutlak untuk memidanakan seseorang, melainkan terdapat aspek melawan hukum materiil (materiele wederrechtelijkheid) yang dapat menjadi pertimbangan hukum hakim. ${ }^{57}$

\section{Penutup}

Dalam lapangan hukum pidana, telah terjadi pergeseran pemahaman sifat melawan hukum (wederrechtelijk), yakni tidak hanya berdasarkan murni undangundang pidana (onwetmatige), namun menggunakan kriteria melawan hukum dalam hukum perdata (onrechmatige). Makna melawan hukum dalam hukum perdata mencakup melanggar kepatutan atau kepantasan di masyarakat juga digunakan dalam hukum pidana untuk memaknai melawan hukum dalam arti materiil. Meskipun demikian, masih terjadi perbedaan pendapat di antara para ahli hukum pidana apakah sifat melawan hukum materiil hanya memiliki fungsi negatif atau juga memiliki fungsi positif. Selanjutnya, perbuatan melawan hukum yang diartikan secara luas dalam perdata dan dikenal dalam hukum pidana sebagai perbuatan melawan hukum secara materiil, dapat dibatasi melalui interpretasi guna menentukan perbuatan yang dilarang yang dikenal sebagai Schutznormtheorie atau ajaran relativitas.

Batas melawan hukum persekongkolan tender dalam wilayah hukum perdata sangat luas karena pendekatan yang digunakan untuk menganalisis tindakan pelanggaran menggunakan pendekatan yuridis dan non yuridis (economic analysis of law). Sedangkan batas melawan hukum persekongkolan tender dalam wilayah hukum pidana terletak pada aturan hukum, baik aturan yang bersifat formil maupun materiil. Tetapi, seiring dengan yurisprudensi dan pemahaman

\footnotetext{
${ }^{56}$ Lihat perbuatan-perbuatan yang dimaksud di bab analisis putusan Mahkamah Agung perkara pengadaan tinta pemilu legislatif tahun 2004.

${ }^{57}$ Barda Nawawi Arief, Pembaharuan Hukum Pidana dalam Perspektif Kajian Perbandingan, Citra Aditya Bakti, Bandung, 2005, hlm. 33-40.
} 
kalangan penegak hukum dapat disimpulkan bahwa sekat-sekat melawan hukum di dalam hukum pidana dan hukum perdata runtuh ketika kasus persekongkolan tender telah melanggar rasa keadilan di masyarakat.

\section{Daftar Pustaka}

\section{Buku}

Agustina, Rosa, Perbuatan Melawan Hukum, Fakultas Hukum Universitas Indonesia, Jakarta, 2003.

Anggraini, AM. Tri, Pendekatan Per Se Ilegal dan Rule of Reason, Fakultas Hukum Universitas Indonesia, Jakarta, 2003.

Arief, Barda Nawawi, Pembaharuan Hukum Pidana dalam Perspektif Kajian Perbandingan, Citra Aditya Bakti, Bandung, 2005.

Asshiddiqie, Jimly, Teori \& Aliran Penafsiran Hukum Tata Negara, Ind. Hill.Co., Jakarta, 1997.

Fuady, Munir, Perbuatan Melawan Hukum (Pendekatan Kontemporer), Citra Aditya Bakti, Bandung, 2005.

Hamzah, Andi, Asas-Asas Hukum Pidana, Edisi Revisi, Rineka Cipta, Jakarta, 2008.

Hansen, Knud, et. al., Undang-Undang Larangan Monopoli dan Persaingan Usaha Tidak Sehat, Katalis, Jakarta, 2001.

Hiariej, Eddy O.S., Prinsip-Prinsip Hukum Pidana, Cahaya Atma Pustaka, Yogyakarta, 2014.

Huda, Chairul, Dari Tiada Pidana Tanpa Kesalahan Menuju kepada Tiada Pertanggungjawban Pidana Tanpa Kesalahan, Kencana, Jakarta, 2006

Kagramanto, L. Budi, Larangan Persekongkolan Tender (Persektif Hukum Persaingan Usaha), Srikandi, Surabaya, 2008.

Marzuki, Peter Mahmud, Penelitian Hukum, Cet 2. Kencana, Jakarta, 2008

Remmelink, Jan, Hukum Pidana: Komentar atas Pasal-Pasal Terpenting dari Kitab Undang-Undang Hukum Pidana Belanda dan Padanannya dalam Kitab UndangUndang Hukum Pidana Indonesia, Gramedia Pustaka Utama, Jakarta, 2003.

Sagers, Christopher L, Antitrust, Second Edition, Wolters Kluwer Law\&Business, USA, 2014.

Saleh, Roeslan, Sifat Melawan Hukum dari Perbuatan Pidana, Aksara Baru, Jakarta, 1981.

Satrio, J., Hukum Perikatan, Perikatan yang Lahir dari Undang-Undang, Bagian Pertama, Citra Aditya Bakti, Bandung, 2001.

Schaffmeister, D., et. al., Hukum Pidana, Citra Aditya Bakti, Bandung, 2007. 


\section{Jurnal}

Doyle, Michael A. \& Michael P. Kenny, "The Statute of Limitations Applicable of Criminal Enforcement of the Sherman Act: Restraint of Trade or Enjoyment of the Spoils?", Arizona State Law Journal 183, 1986.

OECD, Guidelines for Fighting Bid Rigging in Public Procurement, Helping Governments to Obtain Best Value for Money.

Okatanit, Naoaki, "Regulations on Bid Rigging in Japan, the United States and Europe Pacific Rim," Law \& Policy Journal, Vol. 4 No. I, 1995.

Poter, Robert H. and J. Douglas Zona, "Detection of Bid Rigging in Procurement Auctions," Journal of Political Economy Vol. 101 No. 3, 1993.

\section{Peraturan Perundang-Undangan}

Peraturan KPPU No. 2 Tahun 2010 tentang Pedoman Pasal 22 Undang-Undang No. 5 Tahun 1999 tentang Persekongkolan Tender.

Putusan KPPU No. 03/KPPU-I/2002 Tender Penjualan Saham PT Indomobil Sukses International.

Putusan KPPU No. 07/KPPU-L/2004 Tender Penjualan Dua Unit Tanker Pertamina.

Putusan KPPU No. 08/KPPU-L/2004 Tender Pengadaan Tinta Sidik Jari Pemilu Legislatif Tahun 2004.

Putusan KPPU No. 03/KPPU-L/2012 Tender Penerapan Kartu Tanda Penduduk Berbasis NIK Secara Nasional (KTP Elektronik) Tahun 2011 s/d 2012.

Putusan MA No. 275 K/Pid/1983 tanggal 29 Desember 1983.

Putusan Mahkamah Agung No. 2477 K/Pid/1988 tanggal 23 Juli 1993.

Putusan Mahkamah Agung No. 1571 K/Pid/1993 tanggal 18 Januari 1995.

Putusan Mahkamah Konstitusi No. 003/PUU-IV/2006 tanggal 25 Juli 2006.

Undang-Undang No. 31 Tahun 1999 tentang Tindak Pidana Korupsi juncto Undang-Undang No. 20 Tahun 2001.

\section{Internet}

Adidana, Mohammad Yusuf, "Persekongkolan Tender sebagai Suatu Tindakan yang Anti Persaingan Sehat," www.hukumonline.com/berita/baca/ hol18357/persekongkolan-tender-sebagai-suatu-tindakan-yang-antipersaingan-sehat, Akses 22 September 2017.

Anonim, "Ada 2 Penyipangan Pengadaan Tinta Pemilu," news.detik.com/ berita/570691/ada-2-penyimpangan-pengadaan-tinta-pemilu, Akses 5 Maret 2017.

Anonim, "KKN, Penyakit yang Menjangkiti Pengadaan Barang/Jasa Pemerintah Kamis," www.hukumonline.com/berita/baca/hol15346/kkn-penyakityang-menjangkiti-pengadaan-barangjasa-pemerintah-, 24 Agustus 2006. 
Anonim, "KPPU Akan Gandeng LKPP Atasi Kasus Persekongkolan Tender," www.hukumonline.com/berita/baca/lt4c6424cee54ac/kppu-akangandeng-lkpp-atasi-kasus-persekongkolan-tender, 12 Agustus 2010.

Anonim, "KPPU Nilai Inefisiensi Proyek Pemerintah Rp 8,6 T," www.hukumonline.com/berita/baca/lt5105fbb6b7ac6/kppu-nilaiinefisiensi-proyek-pemerintah-rp8-6-t, Akses 28 Januari 2013.

Anonim, "Lanjutan kasus tender Indomobil di Kejagung tergantung ekspose,"www.hukumonline.com/berita/baca/hol5693/lanjutan-kasustender-indomobil-di-kejagung-tergantung-ekspose, Akses 22 September 2017.

Anonim, "Masih Ada Dualisme Pengaturan Pengadaan Jasa Konstruksi," www.hukumonline.com/berita/baca/hol15371/masih-ada-dualismepengaturan-pengadaan-jasa-konstruksi-, akses 29 Agustus 2006.

Anonim, "Mengurai Benang Kusut Tender Indomobil" www.hukumonline.com/berita/baca/hol5719/mengurai-benang-kusuttender-indomobil, akses 21 Februari 2017.

Anonim, "Menkeu Akui Maraknya Korupsi dalam Pengadaan Barang dan Jasa", www.hukumonline.com/berita/baca/lt4cf7563e8e446/menkeu-akuimaraknya-korupsi-di-pengadaan-barang-dan-jasa-," 02 Desember 2010.

Anonim, "Pengadaan Tinta Pemilu Juga Melanggar UU Anti Monopoli" www.hukumonline.com/berita/baca/hol13157/pengadaan-tinta-pemilujuga-melanggar-uu-anti-monopoli, , Akses 5 Maret 2017.

Anonim, "Soal Tender Indomobil MA Batalkan putusan PN dan KPPU,"www.hukumonline.com/berita/baca/hol7230/soal-tenderindomobil-ma-batalkan-putusan-pn-dan-kppu, Akses 22 September 2017.

Anonim, "Soal Tender Indomobil MA Batalkan Putusan Putusan PN dan KPPU," www.hukumonline.com/berita/baca/hol7230/soal-tender-indomobilma-batalkan-putusan-pn-dan-kppu, 16 Januari 2003.

Atriana Rina, "Vonis e-KTP, Hakim: Irman-Sugiharto Terbukti Salahgunakan Wewenang, https://news.detik.com/berita/d-3567145/vonis-e-ktphakim-irman-sugiharto-terbukti-salahgunakan-wewenang, Akses 12 Oktober 2017.

Pradana, B. Dwita, "Penjelasan BPK RI Terkait Penerbitan SP3 VLCC Pertamina" http://www.bpk.go.id/assets/files/attachments/2009/02/sp-vlcc.pdf, Akses 22 September 2017.

Vondrak, Frank J., “Preventing and Detecting Bid Rigging, Price Fixing, and Market Allocation in Post-Disaster Rebuilding Projects: an Antitrust Primer for Agents and Procurement Officials", www.justice.gov/atr/preventingand-detecting-bid-rigging-price-fixing-and-market-allocation-postdisaster-rebuilding, Akses 1 Oktober 2016. 
www.kppu.go.id/docs/laporan_tahunan/laporan\%20kppu\%202009\%20230511.p df, Akses 12 Agustus 2010.

www.kppu.go.id/docs/laporan_tahunan/laporan_tahunan_2008.pdf. Akses 12 Agustus 2010.

www.unisosdem.org/article_printfriendly.php?aid=480\&coid=2\&caid=30,

“Kejagung hentikan penyelidikan Indomobil," Akses 22 September 2017. 